(Notes)

\title{
First Record of Epinephelus areolatus (Perciformes: Serranidae) from Korea
}

\author{
Maeng Jin Kim ${ }^{1}$ and Choon Bok Song ${ }^{1,2 *}$ \\ ${ }^{1}$ Marine and Environmental Research Institute, Jeju National University, \\ Јејu 690-968, Korea \\ ${ }^{2}$ College of Ocean Sciences, Jeju National University, Jeju 690-756, Korea
}

\begin{abstract}
One specimen of Epinephelus areolatus, belonging to the subfamily Epinephelinae of the family Serranidae, was collected by a hook from commercial longline fisheries in the coastal waters of Jeju Island, Korea. This species is mostly similar to E. chlorostigma, but the former is distinguished from the latter by having larger brown spots and a white posterior margin on the caudal fin. We propose a new Korean name "Dae-moon-ba-ri" for E. areolatus.
\end{abstract}

Key words: First record, Epinephelus areolatus, Serranidae, Jeju Island

\section{Introduction}

Sea basses (family Serranidae), comprising three subfamilies of 64 genera with about 475 species, are widely distributed in tropical and temperate seas of the world; a few species, however, inhabit freshwater areas (Nelson, 2006). Grouper genus Epinephelus, belonging to the family Serranidae, comprises about 167 species, inhabiting marine habitats around the world (The Catalog of Fishes On-line: www.calacademy.org). Many of these species are economically important for aquaculture. In Korea, 12 species of Epinephelus have been reported thus far (Kim et al., 2005).

One specimen of Epinephelus areolatus, belonging to the subfamily Epinephelinae of the family Serranidae, was collected by a hook from commercial longline fisheries in the coastal waters of Jeju Island on May 30, 2010. The morphological characteristics of $E$. areolatus were described in order to be added to the list of Korean fish fauna.

\section{Materials and Methods}

Epinephelus areolatus was collected from Daejeongeup, Jeju-do, Korea in may 30, 2010. The comparative materials incluede E. chlorostigma $(\mathrm{n}=1)$ : JNU 20100611, $202.0 \mathrm{~mm}$ SL, longline, Daejeong-eup,

\footnotetext{
*Corresponding author: cbsong@jejunu.ac.kr
}

Jeju-do, Korea. June 11, 2010.

Counts and measurements of this specimen follow the method of Nakabo (2002). The examined specimen was deposited at the Fish Genetics and Breeding Laboratory, Jeju National University (JNU), Korea.

\section{Results and Discussion}

Description. Measurements of morphological traits for the present specimen are shown in Table 1. Measurements are shown as a percentage against standard length (SL): body depth 31.0 ; body width 14.2; head length 35.1 ; upper jaw 13.6; snout length 10.9; eye diameter 6.5 ; interorbital length 6.4 ; predorsal fin 34.0; prepectoral fin 35.0; preanal fin 64.0 ; length of longest dorsal fin ray 11.9; length of longest pectoral fin ray 17.0; length of longest anal fin ray 17.2; caudal peduncle depth 10.6; caudal peduncle length 19.4.

Body was moderately elongated and compressed; mouth slightly large and interorbital space slightly convex; protruding lower jaw more than upper jaw; maxilla extending to hind margin of orbit; posterior margin of preopercle serrated and three spines on corner of preopercle; three large strong spines on opercle; dorsal spines slender and the third longest; pelvic fins triangular and nearly reaching anus; soft part of anal fins rounded, the third longest ray; caudal fin slightly emarginate to truncate. 
Table 1. Comparison of morphological characters of Epinephelus areolatus and E. chlorostigma observed in this study and previously reported

\begin{tabular}{|c|c|c|c|c|c|}
\hline \multirow[b]{2}{*}{ Morphological characters } & \multicolumn{3}{|c|}{ Epinephelus areolatus } & \multicolumn{2}{|c|}{ Epinephelus chlorostigma } \\
\hline & $\begin{array}{l}\text { Present } \\
\text { study }\end{array}$ & Lee (1990) & $\begin{array}{c}\text { Randall and } \\
\text { Heemstra (1991) }\end{array}$ & $\begin{array}{l}\text { Present } \\
\text { study }\end{array}$ & $\begin{array}{c}\text { Randall and } \\
\text { Heemstra (1991) }\end{array}$ \\
\hline Standard length (mm) & $222(n=1)$ & $\begin{array}{c}123-202 \\
(n=2)\end{array}$ & $\begin{array}{c}138-305 \\
(n=35)\end{array}$ & $\begin{array}{c}202 \\
(n=1)\end{array}$ & $\begin{array}{c}117-508 \\
(n=41)\end{array}$ \\
\hline \multicolumn{6}{|l|}{ Counts } \\
\hline Dorsal fin rays & $\mathrm{XI}, 16$ & $\mathrm{XI}, 16$ & $X I, 15-17$ & $\mathrm{XI}, 17$ & $\begin{array}{l}\text { XI, 16-17 } \\
\text { (usually 17) }\end{array}$ \\
\hline Anal fin rays & III, 7 & III, 7-8 & $\begin{array}{c}\text { III, } 7-8 \\
\text { (rarely } 7 \text { ) }\end{array}$ & III, 8 & III, 8 \\
\hline Pectoral fin rays & 17 & $17-18$ & $\begin{array}{c}17-19 \\
\text { (rarely 19) }\end{array}$ & 17 & $\begin{array}{c}17-19 \\
\text { (rarely 19) }\end{array}$ \\
\hline Ventral fin rays & $\mathrm{I}, 5$ & - & - & I, 5 & $\mathrm{I}, 5$ \\
\hline Branched caudal fin rays & 15 & 15 & - & 15 & - \\
\hline Lateral line scales & 51 & - & $49-53$ & 48 & $48-53$ \\
\hline Lateral scale series & 106 & - & $97-116$ & 102 & $96-125$ \\
\hline Gill rakers & $8+14$ & $9+14$ & $8-10+14-16$ & $8+15$ & $8-11+14-18$ \\
\hline
\end{tabular}
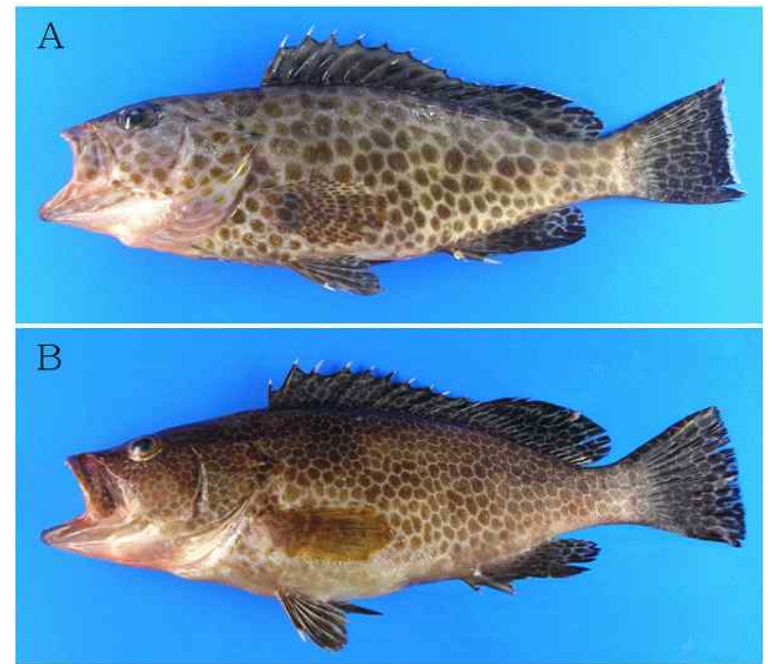

Fig. 1. A: Epinephelus areolatus, JNU 20100530, $222.0 \mathrm{~mm}$ SL; B: E. chlorostigma, JNU 20100611, $202.0 \mathrm{~mm}$ SL.

Color in fresh. Densely covered with rounded or polygonal yellow brown spots on body, head and all fins; whitish posterior margin of the caudal fin.

Color in alcohol. Body uniformly pale brown; dark brown spots on body, head and all fins; gray posterior margin of the caudal fin.

Distribution. Western Pacific from southern Japan to northern Queensland, Australia, and west to the
Persian Gulf, Red Sea, East Africa (Heemstra and Randall, 1986; Randall and Heemstra, 1991), and the western coastal waters of Jeju Island, Korea (present study).

Remarks. The present specimen, collected from the coastal waters of Jeju Island, Korea, was characterized by having many dark brown spots on the body and a white posterior margin of the caudal fin. The morphological characteristics of the specimen matched the species description given by previous studies (Randall and Heemstra, 1991; Senou, 2002) and all counts of the present specimen coincide with those of Randall and Heemstra (1991) (Table 1). E. areolatus is morphologically similar to E. chlorostigma, but the former is distinguished from the latter by having larger brown spots and a white posterior margin on the caudal fin (Senou, 2002; Fig. 1). We propose a new Korean fish name, "Dae-moon-ba-ri," for $E$. areolatus.

\section{Acknowledgments}

This work was funded by a grant from the National Fisheries Research \& Development Institute (RP2010-FR-052).

\section{References}

Allen GR and Swainston R. 1988. The marine fishes of 
north-western Australia. A field guide for anglers and divers. Western Australian Museum, Perth, i-vi+1-201.

Dor M. 1984. CLOFRES-Checklist of the fishes of the Red Sea. Israel Academy of Sciences and Humanities, ixxii+1-437.

Forsskål P. 1775. Descriptions animalium avium, amphibiorum, piscium, insectorum, vermium; quae in itinere orentali observavit. Post mortem auctoris edidit Carsten Niebuhr. Hauniae, 164p.

Heemstra PC and Randall JE. 1986. Family No. 166: Serranidae In: Smiths' Sea Fishes. Smith MM and Randall JE, eds. Springer-Verlag, Grahamstown, 509537.

Lee S-C. 1990. A revision of the serranid fish (family Serranidae) of Taiwan. Journal of Taiwan Museum 43, $1-72$.

Katayama M. 1984. Family Serranidae. In: The fishes of the Japanese Archipelago. Masuda, H, Amaoka K, Araga C, Uyeno $\mathrm{T}$ and Yoshino $\mathrm{T}$, eds. Tokai Univ Press, Tokyo, 126-138.

Kim IS, Choi Y, Lee CL, Lee YJ, Kim BJ and Kim JH. 2005. Illustrated book of Korean fishes. Kyohak Publishing Co Ltd, 613p.

Mohsin AKM and Ambak MA. 1996. Marine fishes and fisheries of Malaysia and neighbouring countries.
Universiti Pertanian Malaysia Press iv-xxxvi+1-744.

Nakabo T. 2002. Fishes of Japan with pictorial keys to the species, English edition, Tokai Univ Press, Tokyo, xxi-xlii.

Nelson JS. 2006. Fishes of the world. 4th edition. John Wiley and Sons Inc, Hoboken, New Jersey, 601p.

Randall JE. 1995. Coastal fishes of Oman. Crowford House Publishing Pty Ltd, Bathurst, Australia, 1-439.

Randall JE and Heemstra PC. 1991. Revision of IndoPacific groupers (Perciformes: Serranidae: Epinephelinae), with descriptions of five new species. IndoPacific Fishes 20, 1-332.

Randall JE and Lim KKP. 2000. A checklist of the fishes of the South China Sea. The Raffles Bull Zool Suppl 8, 569-667.

Sadovy Y and Cornish AS. 2000. Reef fishes of Hong Kong. Hong Kong University Press. Reef fishes of Hong Kong, i-xi+1-321.

Senou H. 2002. Serranidae. In: Fishes of Japan with pictorial keys to the species. English edition. Nakabo T. ed. Tokai Univ Press Tokyo, 690-731.

(Received 4 November 2010; Revised 26 November 2010; Accepted 7 December 2010) 